\title{
Ouvrages phares de la Réforme et de la Contre-réforme dans le collections montréalaises, éd. Brenda Dunn- Lardeau
}

\section{Michele Mastroianni}

\section{(2) OpenEdition}

\section{Journals}

Edizione digitale

URL: http://journals.openedition.org/studifrancesi/5282

DOI: $10.4000 /$ studifrancesi.5282

ISSN: 2421-5856

Editore

Rosenberg \& Sellier

\section{Edizione cartacea}

Data di pubblicazione: 1 dicembre 2016

Paginazione: 515

ISSN: 0039-2944

\section{Notizia bibliografica digitale}

Michele Mastroianni, « Ouvrages phares de la Réforme et de la Contre-réforme dans le collections montréalaises, éd. Brenda Dunn-Lardeau », Studi Francesi [Online], 180 (LX | III) | 2016, online dal 01 janvier 2017, consultato il 18 septembre 2020. URL : http://journals.openedition.org/studifrancesi/ 5282 ; DOI : https://doi.org/10.4000/studifrancesi.5282

Questo documento è stato generato automaticamente il 18 settembre 2020.

\section{cc) (i) 8}

Studi Francesi è distribuita con Licenza Creative Commons Attribuzione - Non commerciale - Non opere derivate 4.0 Internazionale. 
Ouvrages phares de la Réforme et de la Contre-réforme dans le collections montréalaises, éd. Brenda DunnLardeau

Michele Mastroianni 


\section{NOTIZIA}

Ouvrages phares de la Réforme et de la Contre-réforme dans le collections montréalaises, sous la direction de Brenda DUNN-LARDEAU, Québec, Presses de l'Université du Québec, 2014, 329 pp.

Questo interessante volume, centrato su indagini relative alla circolazione, ricezione e presenza di testi della Riforma e Controriforma conservati a Montréal presso la Bibliothèque et Archives Nationales du Québec, fra cui catechismi, messali, bibbie ebraiche, ginevrine, poliglotte, ecc., è anche il risultato di seminari di studio, tenuti a partire dal 2012, che si sono posti come principale obiettivo quello di rendere noto alla comunità scientifica parte del patrimonio culturale e librario di cui dispone il Québec, patrimonio poco noto in ambito europeo. Indirizzato soprattutto al filologo e all'interesse del bibliofilo di area cinquecentesca, la pubblicazione di questi atti ha il merito di informare lo studioso sul numero di opere pubblicate durante la Riforma, e disponibili a Montréal, rispetto a quelle che circolavano, sempre a Montréal, nel periodo della Controriforma. Non solo. Molte delle indagini che sottostanno alla realizzazione di questo volume si sono concentrate su libri stampati a Parigi e a Ginevra per i tipi degli Estienne o per quelli, a Lione, dei Frellon. Il volume, oltre al dato erudito e antiquario riporta una serie di immagini di cinquecentine rare e preziose e un'utile bibliografia che si offre come strumento di interesse per lo studioso. 